\title{
Is it true that educator certification guarantees professional teachers?
}

Mitri Irianti, Physics Education Program, Riau University, Pekanbaru, Indonesia; mitri.irianti@gmail.com;
ORCID: 0000-0002-9494-5237
*Almasdi Syahza, Economic Education Program, Riau University, Pekanbaru, Indonesia;
almasdi.syahza@lecturer.unriac.id; ORCID: 0000-0003-1714-2104
$\begin{array}{llll}\text { Suarman, Economic Education Program, Riau University, Pekanbaru, } & \text { Indonesia; }\end{array}$ suarman@lecturer.unri.ac.id; ORCID: 0000-0002-2739-3575

*Corresponding Author

\begin{abstract}
The research objective is to determine the impact of certification on teacher performance in the learning process in an effort to improve the quality of learning and the quality of education in the school environment. To find out the impacts of the implementation of the government policy on teacher performance, a special test was conducted, comparing certified and uncertified teachers. Their performance would be observed based on four competencies namely pedagogic, personality, social, and professional. The results showed, overall there was no difference in performance between certified teachers and uncertified teachers. This condition is seen in the component of the teacher's pedagogical and professional abilities. Teachers who have been certified have not had an impact on improving their performance. The certified teachers should have a much better performance than non-certified teachers, however apparently not show the difference. In order that professional improvement training for certified teachers is needed.
\end{abstract}

Keywords: teacher performance; policy implementation; pedagogic; certified teacher; educator certificate

$\begin{array}{lll}\text { Received: } 17.11 .2020 & \text { Accepted: } 10.12 .2020 & \text { Published: 05.01.2021 }\end{array}$

\section{INTRODUCTION}

The essence of the national development is the total development of Indonesian people both as an individual and as the entire nation. The development achievement is no longer measured in the economic terms, but how it can improve the human resources (HR) quality. Today, sustainable development is not only supported by the economic development but also with improvement in human resources. Therefore, investment in human resources aspects as the basic capital of development is highly prioritized.

Improved quality of human resources is also a growing demand resulting from the increasingly fast and complex development. Economic development, industrialization, information flow and rapid progress in science and technology require better qualities of human resources. In the long term, human resources development is undertaken based on four policies: 1) improved quality of life, which includes the quality of human being, such physical, emotional and psychological well-being; 2) improved quality of human resources in productivity and efforts to spread them; 3) improved quality of human resources in making use, developing and mastering science and technology; 4) institutional development that includes development of institutions and tools supporting improved quality of human resources.

Currently, the Indonesian human resources have potential for becoming a component of development resources. Human resources are growing rapidly, but their quality remains poor, and therefore, their potential as development resources cannot be utilized to the maximum. Human resources is one the dynamic factors in the long-term economic development, together with science and technology. Consequently, human resources are highly influenced by improved quality of education.

To meet the target of quality learning at every level of education, the Government has published Law No. 14 of 2005 concerning Teachers and Lecturers. Teacher certification is a form of the implementation of this law. The legal basis used as a reference for implementing the certification of inservice teachers includes: 1) Law No. 20 of 2003 concerning National Education System; 2) Law No. 14 of 2005 concerning Teachers and Lecturers; 3) Government Regulation No. 19 of 2005 concerning National Education Standard; 4) Government Regulation No. 74 of 2008 concerning Teacher; 5) Regulation of the National Education Minister No. 16 of 2007 concerning Standard of Teacher Qualifications and 
Competencies. To improve the quality of the education workforce and implement those government policies, teachers and lecturers must be certified.

Teacher certification has been carried out in Indonesia since 2007. Policies concerning implementation of teacher certification have always been amended to make them accountable and provide substantial benefits for improving the learning process. The government policy on teacher certification is targeted to enhance the quality of education, from the early childhood up to higher education. In addition to enhancing teacher's quality, the Government also gives rewards to improve teacher's welfare by providing professional allowance for teachers. Thus, as teachers, they should not only be professional, but also prosperous.

A professional teacher is able to produce quality education, which can be attained by creating a pleasant learning atmosphere. In the teaching-learning process, it is not only students who are required to have motivation to learn, but teachers should also have the same motivation to encourage themselves as well as their students. They should be able to raise their students' enthusiasm for learning and empower their ability to the best possible results ini the teaching-learning process. The motivation created by a teacher should encourage every student to improve their abilities in the teaching-learning process. A motivated person will create a strength within himself to do something, in this case it will certainly influence the way he learns and his learning ability. Synergistically, it will impact on students' ability to absorb learning materials and their behavior.

The entire teachers' activities related to their professional development can be seen from their own performance. Performance is an ability to work or work achievement of a teacher to produce optimum results. Performance represents an action or activity undertaken by a teacher in his professional service. Performance of a teacher will be reflected in daily situation and work conditions. Activities carried out by a teacher related to his profession describe how he is working to reach the goal that has been set. Performance is the results of the work achieved and can be reflected in the quality of work, punctuality, initiatives, skills and good communication.

Law No. 14 of 2005 concerning Teachers and Lecturers states that teachers are professional educators with the main duties to educate, teach, guide, direct, train, assess and evaluate students in formal education at the level of early childhood, primary and secondary education. A professional teacher should have a minimum academic qualification that is equivalent with bachelor degree (S-1) or diplome four (DIV), related competencies (pedagogic, professional, social and personality), educator certificate, good physical and spiritual health, and ability to achieve the goal of the national education.

Teachers hold a position of a professional at the level of primary, secondary and early childhood education in formal education, who are appointed in accordance with law and regulations. The recognition of teacher as a professional is proven with educator certificate. Furthermore, Law No. 14 of 2005 concerning Teachers and Lecturers defines that a profession is a job or an acitivity performed by a person and become his source of livelihood, which requires expertise, skills, or abilities that meet a standard of quality or certain norms, as well as professional education. As professionals, teachers are expected to strengthen the dignity and the role of teachers as agents of learning that are required to improve the quality of the national education. Teacher certification that is intended to enhance the quality of teachers is expected to be able to improve learning and education quality in Indonesia in a sustainable way.

To become a professional in teaching work, teaching skills must be trained. The dominant reason to improve teaching skills is a strong motivation within oneself to work and try. According to Ankli et al (2012), work motivation was one of the factors that also determined someone's performance. How great is the effect of motivation on someone's performance depends on how great the intensity of motivation is given. Teachers' work motivation is a process undertaken to move teachers so that their behavior can be directed to concrete efforts to achieve the stated goals. Furthermore, Amar (2004), Akkermans et al (2016), Kongcharoen et al (2019), Roche et al (2019), defined motivation as a driving force that generates work excitement in someone, so he is willing to cooperate, work effectively, integrate the driving force with all his efforts to achieve satisfaction.

Study related to education policy was conducted by Irs eta al (2012), the ability of school management is very important to improve teacher performance, and factors related to appreciation for teacher performance at school need to be considered. According to Irs (2012), school principals and teachers had a positive attitude towards improved education because of the provision of performance allowances. Shauki et. al. (2009), revealed that teacher performance made a contribution to education, especially improving student's abilities. Performance allowance policies had an impact on teacher's motivation. The results of the study conducted by Liu et al (2016), Ocham et al (2015), showed that teacher motivation was a means to improve the quality of the school management performance. Teacher performance must be recognized by providing rewards and other incentives. Teachers are given responsibilities and freedom to take action to develop their abilities in school. Tan et al (2012), discussed 
the problems and challenges faced in the development of teacher's profession, intertwined in the complexities of educational reform, community development and economy. Efforts to improve teacher's professionalism faced several structural, economic and socio-cultural challenges.

Me Clelland presented 6 characteristics of teachers with motivation to have remarkable achievement, namely: 1) having a great sense of personal responsibility; 2) not afraid to take a risk; 3) having realistic goals; 4) making use of the comprehensive work plan and striving to attain its goals; 5) making use of concrete feedbacks in the entire activities related to their job; and 6) finding the opportunity to realize their programmed plan ( $\mathrm{Naeem}_{\llcorner}$et al, 2019).

Teacher is an agent of education. The quality of a teacher highly determines his expertise in delivering educational messages. A teacher's expertise will determine his ability to deliver teaching materials to his students. A teacher must be qualified in the subject he teaches. Therefore, a teacher is a professional and qualified educator.

The objective of this study is to determine the impact of the teacher certification policy on the quality of education and teacher performance at the secondary education level. To achieve this objective, some information is needed, including: 1) the ability of certified teachers in the learning process to improve the quality of learning and education in their school; 2) the impacts of certification on improved teacher performance in terms of pedagogic and professional aspects in their work environment.

\section{METHODS}

This study was conducted through a survey using the Developmental Research method. To obtain general information about the impacts of the government policies on teacher performance in the education sector, this study made use of a lot of primary data obtained through surveys. This study was conducted in Kampar District, Rokan Hulu District, Pelalawan District, and Pekanbaru City. The target population was teachers in senior high schools (SMA) and junior high schools (SMP). The select schools were assumed to have different infrastructure and facilities. In the select regions, teachers and schools were selected to become samples. Sampling was done intentionally with criteria that included: 1) teachers from the governmentowned schools; 2) teachers who had been in service for at least 5 years; 3 ) subject matter teachers.

To find out the impacts of the implementation of the government policy on teacher performance, a special test was conducted, comparing certified and uncertified teachers. Their performance would be observed based on four competencies namely pedagogic, personality, social, and professional. The four components would be assessed using 14 indicators and 78 sub-indicators by the research team and the school principal. The test used in this study was the T-test. After the T-test was completed, a descriptive analysis was carried out to describe the performance of junior and senior high school teachers who have and have not been certified. Besides looking at competencies, the study also discussed the pedagogic ability and professionalism of certified teachers.

\section{RESULTS}

Improved education quality is determined by the readiness of human resources (HR) involved in the education process. Teacher is one of the human components in the teaching and learning process. Teacher plays a role in generating HR who have potential in the development area. Every teacher is supposed to be able to teach in the classroom. Even teaching can be done also to a group of students outside the classroom or anywhere. Teaching is one component of teacher's competencies. Every teacher should master it and competent at teaching. Teaching is not an easy task for a teacher. In teaching, teachers are dealing with a group of students, future leaders who need guidance and fostering. Teachers with adequate teaching experience are usually proficient and competent at teaching.

Teacher's skills are professional expertise generated through the teaching and learning process. Professional expertise is one supporting factor in the implementation of teaching and learning activities. Teacher's expertise in delivering subject materials to students is one of the determining factors to achieve successful learning. Professional teacher must demonstrate their skills in the learning process. Professional teachers will win the heart of their students and their presence in the classroom is always expected.

The implementation of the teacher certification policy in Riau was based on a teacher performance assessment conducted by the school. Variables examined in the assessment were pedagogic, personality, social, and professional aspects of teacher performance.

\section{Pedagogic Competency}

Pedagogic competence is the ability to understand students, make a learning plan and implement learning activities, evaluate learning outcomes, and develop students to actualize various potentials they have. Pedagogic competency is measured against 7 sub-indicators, namely: 1) able to deal with the 
characteristics of students; 2) master learning theory and principles of education and learning; 3) curriculum development; 4) education and learning activities; 5) development of students' potential; 6) communication with students; and 7) assessment and evaluation.

The results of the analysis show that the percentage of uncertified teachers who have good and very good performance reached $90.7 \%$, while certified teachers with good and very good performance $78.41 \%$. The rest had performance at the moderate level. The T-test results show that $\mathrm{t}$-count was smaller than $\mathrm{t}$ table $(1,188<2,617)$. These results indicate that in the pedagogic aspect, certified teachers do not show any significant difference compared to uncertified teachers (presented in Table 1). The government expects that teacher certification is able to improve the performance of teachers as agents of learning in generating smart students, but after being certified, their performance does not meet the expectation.

Table 1. Teacher performance assessment with pedagogical competency indicators

\begin{tabular}{|l|l|l|l|l|}
\hline \multirow{2}{*}{ Pedagogical competency } & \multicolumn{5}{l|}{ Certification } & \multicolumn{2}{l|}{ Non-certification } \\
\cline { 2 - 5 } & Frequency & $\%$ & Frequency & $\%$ \\
\hline Very good & 18 & 20.45 & 3 & 6.98 \\
\hline Good & 51 & 57.95 & 36 & 83.72 \\
\hline Fair & 19 & 21.59 & 4 & 9.30 \\
\hline Poor & 0 & 0.00 & 0 & 0.00 \\
\hline Total & 88 & 100 & 43 & 100 \\
\hline Total & 131 & & & \\
\hline Very good and good (\%) & 78.41 & 90.70 & \\
\hline Fair (\%) & 21.59 & 9.30 & \\
\hline Poor (\%) & 0.00 & 0.00 & \\
\hline
\end{tabular}

$\mathrm{t}_{\text {count }}=1.188 ; \mathrm{t}_{\text {table }}=2.617(\alpha=1 \%)$ and $1.600(\alpha=5 \%)$

The poor performance of certified teacher can be seen from their ability to understand the characteristics of students. They still adopt the old teaching method, and they even have poor understanding about learning theories and principles of learning. Likewise, in terms of learning development, certified teachers tend to pay more attention on teaching materials, and less attention to selfdevelopment. Schools also rarely conduct trainings for teachers and improve teacher's skills, so that certified teachers focus their attention to meet the minimum teaching hours requirement of 24 hours per week.

\section{Personality Competency}

Personality competency is a personal ability that reflects a steady, stable, mature, wise, and authoritative personality that becomes a good model for students, and have noble deeds. Indicators of personality competency that are used to assess teacher performance are: 1) Acting in accordance with religious, legal, social and cultural norms, and also national culture; 2) Showing mature personality and becoming a good model; and 3) having work ethic, a great sense of responsibility, and a sense of pride in being a teacher.

In terms of the personality competency, the results of the mathematical analysis of teacher performance in Riau Province are better than those of the pedagogical aspect. The percentage of certified teachers who have good and very good performance reached $97.73 \%$, while uncertified teachers with good and very good performance only $72.09 \%$ (presented in Table 2). Likewise, the analysis using the T-test shows that certified teachers had better performance. This condition is proven by the $t$-count value that was greater than $\mathrm{t}$-table $(3.355<2.617)$.

Better performance of certified teachers in the personality aspect indicates that the certification policy has an impact on teacher performance that is measured against their ability to act in accordance with religious, legal, social and cultural norms as well as national culture. This is because the certification policy is able to change the socio-economic status of teachers, especially in society. Teacher certification has increased teacher's income which has an impact on the personality aspect. Better financial conditions result in better personality of teachers. On the other hand, uncertified teachers have not been able to improve their welfare through their income as teachers, and it makes them feel inferior in their work environment and in society. 
Table 2. Teacher performance assessment with personality competency indicators

\begin{tabular}{|l|l|l|l|l|}
\hline \multirow{2}{*}{ Personality competency } & \multicolumn{5}{l|}{ Certification } & \multicolumn{2}{l|}{ Non-certification } \\
\cline { 2 - 5 } & Frequency & $\%$ & Frequency & $\%$ \\
\hline Very good & 27 & 30.68 & 7 & 16.28 \\
\hline Good & 59 & 67.05 & 24 & 55.81 \\
\hline Fair & 2 & 2.27 & 12 & 27.91 \\
\hline Poor & 0 & 0.00 & 0.00 & 0.00 \\
\hline Total & 88 & 100 & 43 & 100 \\
\hline Total & 131 & & \\
\hline Very good and good $(\%)$ & 97.73 & 72.09 & \\
\hline Fair $(\%)$ & 2.27 & 27.91 & \\
\hline Poor $(\%)$ & 0.00 & 0.00 & \\
\hline & $t_{\text {count }}=3.355 ; t_{\text {table }}=2.617(\alpha=1 \%)$ and $1.600(\alpha=5 \%)$ \\
\hline
\end{tabular}

\section{Social Competency}

Social competency is the ability of teachers to communicate and socialize effectively with students, education personnel, parents/guardians of students, and surrounding communities. Indicators of social competence are: 1) being inclusive, acting objectively, and not discriminating; 2) communication with fellow teachers, education personnel, parents of students and community. The two indicators are reflected in teacher performance, among others: a) teachers treat students fairly; b) teachers establish good relationship and care about their colleagues, and contribute positively to all formal and informal discussions related to their work; c) teachers interact frequently with students and do not limit their attention to certain groups of students; d) teachers deliver information about the progress, problems, and potential of students to their parents, both in formal and informal meetings between teachers and parents, peers, and can show the evidence; e) teachers take an active role in activities outside the classroom organized by schools and community and can prove their participation; f) teachers pay attention to the school as part of the community, communicates with surrounding communities, and play a role in social activities in society. The results of teacher performance assessment in Riau Province using the social competency indicators are presented in Table 3.

The results of the study show that the percentage of certified teachers with good performance in social competency was only $38.64 \%$, while the percentage of those that are not certified was only $27.91 \%$. The percentage of certified and uncertified teachers showing relatively poor performance in terms of social competency was relatively low: $61.36 \%$ and $62.79 \%$ respectively. Low percentage of teachers with good performance in social competency is mainly due to the relatively heavy workload of teachers, especially for certified teachers who have to teach at least 24 hours per week and work on additional assignments. This situation results in a lack of social interactions with fellow teachers, parents and students.

Observation reveals that social competency of certified and uncertified teachers have a significant difference. The results of the statistical analysis show that certified teachers in terms of social competency have better performance compared to uncertified teachers, as indicated in t-count that is greater than $\mathrm{t}$ table (3.275> 2.617). This is because certified teachers have an advantage over their uncertified fellows, especially in terms of social status. They pay more attention to maintaining the prestige as certified teacher. 
Table 3. Teacher performance assessment with social competency indicators

\begin{tabular}{|c|c|c|c|c|}
\hline \multicolumn{5}{|l|}{ Social competency } \\
\hline \multirow{2}{*}{ Performance } & \multicolumn{2}{|c|}{ Certification } & \multicolumn{2}{|c|}{ Non-certification } \\
\hline & Frequency & $\%$ & Frequency & $\%$ \\
\hline Very good & 13 & 14.77 & 2 & 4.65 \\
\hline Good & 21 & 23.86 & 10 & 23.26 \\
\hline Fair & 54 & 61.36 & 27 & 62.79 \\
\hline Poor & 0 & 0.00 & 4 & 9.30 \\
\hline Total & 88 & 100 & 43 & 100 \\
\hline Total & \multicolumn{4}{|l|}{131} \\
\hline Very good and good (\%) & \multicolumn{2}{|l|}{38.64} & \multicolumn{2}{|l|}{27.91} \\
\hline Fair $(\%)$ & \multicolumn{2}{|l|}{61.36} & \multicolumn{2}{|l|}{62.79} \\
\hline Poor (\%) & \multicolumn{2}{|l|}{0.00} & \multicolumn{2}{|l|}{9.30} \\
\hline
\end{tabular}

\section{Professional Competency}

Professional competency is the broad and deep understanding of learning materials, which includes understanding of curriculum materials of subjects in schools and scientific substance of the materials, as well as understanding of scientific structure and methodology. Certification is one indicator showing that a teacher has reached the level of professional. Professionalism of a teacher constitutes his ability to develop the potential within himself, so he is able to transfer it to others, especially to students. The presence of a professional teacher in the classroom is always expected by his students.

Performance of a teacher as an agent of learning regarding his professional competency is measured against several indicators as follows: First, have thorough understanding of materials, structure, concepts, and scientific thinking patterns that support the subjects being taught. This indicator consists of the following subindicators: a) teachers conduct the mapping of standard of competency and basic competency for the subjects they teach, identify learning materials that are considered difficult, do the planning and implement the learning activities, and estimate the allocation of time required; b) teachers include appropriate and up-to-date information in the planning and implementation of learning activities; c) teachers prepare materials, planning and implementation of learning activities containing appropriate and up-to-date information, and which help students understand the concept of the learning materials.

Second, develop professionalism through reflective actions. This component consists of several subindicators as follows: a) teachers conduct a self-evaluation specifically, comprehensively, and supported by examples of self-experience; $b$ ) teachers have a learning journal, input notes from colleagues or results of the learning process assessment as evidence that describes their performance; c) teachers utilize the evidence of their performance to develop the planning and implementation of further learning in the PKB program; d) teachers are able to apply their PKB experience in the planning, implementation, and evaluation of learning activities and the follow-up actions; e) teachers conduct researchs, develop innovative works, participate in scientific activities, and are active in implementing the PKB program; f) teachers are able to use ICT in the communication and implementation of PKB.

The results of the analysis of certified teachers performance in terms of the professional competency show that their performance has not reached a good level. Of the respondents observed, only $1.14 \%$ of teachers had good performance, $78.41 \%$ had moderate performance and the rest had not been able to provide good performance in accordance with their professional demands. Based on the results of the analysis presented in Table 4, uncertified teachers also show poor performance. Statistically the performance of certified and uncertified teachers does not show a significant difference. It means that the performance of certified teachers is not much different from those who have not been certified. It is proven by the $\mathrm{T}$-test indicating that the $\mathrm{t}$-count was smaller than the $\mathrm{t}$-table $(0.360<2.617)$. In conclusion, certified teachers have not been able to implement their professionalism.

Giving a certificate to professional teachers is the government's appreciation for their performance and for providing optimal satisfaction to their customers, who in this case are students and community. Teachers who have received an educator certificate should be able to show their professionalism and responsibilities for being professional teachers. Professionalism of a teacher is reflected in his attitude and behavior as an educator in schools and in society. 
Table 4. Teacher performance assessment with professional competency indicators

\begin{tabular}{|l|l|l|l|l|}
\hline \multirow{2}{*}{ Professional competency } & \multicolumn{5}{l|}{} \\
\cline { 2 - 5 } & Certification & \multicolumn{2}{l|}{ Non-certification } \\
\cline { 2 - 5 } & Frequency & $\%$ & Frequency & $\%$ \\
\hline Very good & 0 & 0.00 & 0 & 0.00 \\
\hline Good & 1 & 1.14 & 0 & 0.00 \\
\hline Fair & 69 & 78.41 & 32 & 74.42 \\
\hline Poor & 18 & 20.45 & 11 & 100 \\
\hline Total & 88 & 100 & 43 & \\
\hline Total & 131 & \multicolumn{5}{l}{} \\
\hline Very good and good (\%) & 1.14 & 0.00 & \\
\hline Fair (\%) & 78.41 & 74.42 & \\
\hline Poor (\%) & 20.45 & 25.58 & \\
\hline
\end{tabular}

$\mathrm{t}_{\text {count }}=0.360 ; \mathrm{t}_{\text {table }}=2.617(\alpha=1 \%)$ and $1.600(\alpha=5 \%)$

The government expects that certified teachers are able to demonstrate better performance compared to those who have not been certified, but the results of the analysis do not show a significat difference between certified and uncertified teachers in terms of professional competency. This condition occurs because of several factors. Certified teachers still have problems in mapping standard of competency and basic competency for the subjects they teach. They have not been able to identify complex learning materials, are still weak in planning and implementing learning activities as well as estimating the time allocation required. The learning plan made by these certified teachers is still following the classic model and old practice. So, there is no innovation in the learning plan. In preparing teaching materials, teachers still highly depend on standard textbooks, so they are unable to find other sources to enrich their teaching materials.

\section{Teacher Performance Competency (Pedagogic, Social, Personality, and Professional)}

The field observation shows that certified teachers have not been able to make use of the evidence of their performance for developing a learning plan and implementing the PKB program in their workplace, let alone preparing teaching materials. Lack of $\mathrm{PKB}$ activities impacts on their abilitiy to gain thorough understanding of subject materials, resulting in limited teaching materials to be delivered to students. Teachers are still poor with general knowledge and still stick to the materials that are already in the school textbooks. The results of the analysis of the four components of teacher's competency are presented in Table 5.

The results of the field observation give information that based on teacher performance indicators consisting of pedagogic, personality, social and professional competencies, certified teachers did not show any significant difference from uncertified teachers. It was uncertified teachers with percentage of $100 \%$ showing good and very good performance. On the other hand, the percentage of certified teachers whose performance are good and very good was 78.41\%. This is because teachers who have not been certified have high work motivation to get the opportunity to be certified.

Table 5. Teacher performance assessment with performance competency indicators (pedagogic, social, personality, and professional)

\begin{tabular}{|l|l|l|l|l|}
\hline \multirow{2}{*}{ Performance } & \multicolumn{2}{|l|}{ Certification } & \multicolumn{2}{l|}{ Non-certification } \\
\cline { 2 - 5 } & Frequency & $\%$ & Frequency & $\%$ \\
\hline Very good & 10 & 11.36 & 29 & 67.44 \\
\hline Good & 59 & 67.05 & 14 & 32.56 \\
\hline Fair & 19 & 21.59 & 0 & 0.00 \\
\hline Poor & 0 & 0.00 & 0 & 0.00 \\
\hline Total & 88 & 100 & 43 & 100 \\
\hline Total & 131 & \multicolumn{2}{l}{} \\
\hline Very good and good (\%) & 78.41 & 100.00 & \\
\hline Fair (\%) & 21.59 & 0.00 & \\
\hline Poor (\%) & 0.00 & 0.00 & \\
\hline
\end{tabular}

$\mathrm{t}_{\text {count }}=2,343 ; \mathrm{t}_{\text {table }}=2.617(\alpha=1 \%)$ and $1.600(\alpha=5 \%)$ 


\section{DISCUSSION}

In terms of professional development, very rarely certified teachers make improvements to the learning process through research and scientific writing. Certified teachers are still busy with the main task of teaching and preparing teaching materials, so they do not have time to improve the learning process. The ability to write scientific papers for journals is very poor. As a result, these teachers have not been able to deliver teaching materials and gain thorough understanding of subject materials up to standard. Concerning research activities, certified teachers have not been able to make scientific work to prove their professionalism. In the learning process these teacher has not been able to create innovation in learning, both in school and in the classroom.

Based on the previous elaboration of the four competencies (pedagogic, social, personality, and professional competencies) it can be concluded that the certification policy has not given a positive impact on improved teacher performance. However, in terms of social and personality competencies the performance of certified teachers is better than those who have not been certified. In general, the results of the study provide information that the teacher certification policy has not been able to improve teacher performance. Teachers competing to take part in certification are essentially aimed at getting professional allowances equivalent to their basic salary. The title of certified teacher has not been able to improve their performance.

The results of Ree et al (2015) study in Indonesia found that increasing salaries of primary school teachers significantly increased teacher satisfaction with their income, reducing teacher side jobs outside working hours, and reducing household financial pressures. However, after two and three years, salary increases cause no increase in teacher efforts and have no impact on student learning outcomes. The teacher is unable to show his competence as a professional in the field of teaching. Nasra et al (2019), to improve the performance of teachers in schools the role of the principal's leadership is needed, especially to increase teacher competence in their teaching duties.

On the other side, teaching experience (the length of the teaching profession) does not guarantee that a teacher can be professional in his job. Teaching experience does not have an influence on teacher performance. This is caused by several factors, including lack of expertise in preparing teaching materials (especially pedagogic competency), tendency to use or copy the existing teaching materials. Teachers have always been focused on textbooks, lack of efforts to improve their skills, lack of ability to develop their knowledge, so it is limited to teaching materials.

Teacher performance is basically a demonstration of work carried out by teachers when they perform their duties as educators. The quality of teacher performance will highly determine the quality of education output because teachers are people who have the most direct contact with students in the education process in schools. According to Pablos et al (2008), teacher performance was influenced by the ability and motivation factors. A teacher's ability consists of potential ability (IQ) and concrete ability (knowledge+skill). It means that teachers who have a higher educational background that fits their work and the right skills to carry out daily work will achieve the expected performance more easily. Placement of a teacher in the right post will help increase the effectiveness of learning.

Performance evaluation is a system and method of evaluating the work achievement of a company or organization and every individual working in and for the company or organization (Govaerts et al, 2013; Junior et al, 2018; Orr et al, 2019; Romule et al, 2019). There are several indicators that demonstrate teachers' role in improving their abilities in the teaching-learning process: the ability to make a teaching and learning plan, ability to carry out teaching and learning activities, and ability to evaluate the results of the teaching and learning process.

According to Rogge (2011), school supervisors placed teacher performance in the relative perspective for optimum evaluation. Stakeholders' opinion is needed in the evaluation of teacher and school principal performance. Relative strengths and weaknesses of teachers will soon be identified and addressed. Relating to the learning process, Wang et al (2019) pointed out that dynamic strategies were preferred by teachers because these strategies had severe limitations that ignored the complexity of teacher's effectiveness and narrow the concept to each teacher, especially in the classroom context. The proposed conceptual framework could give a new learning direction and improve the effectiveness of teachers in particular, and schools in general.

Teacher participation in the performance evaluation system significantly influences the procedural fairness perceived by teachers. The role of school leaders is actually crucial. From teachers' point of view, charismatic leadership directly and indirectly impacted on improvement in their performance at school (Tuytens et al, 2012). Brown (2005) saw that the effectiveness of the school management operation was determined by the school principal. Improved teacher performance requires support of adequate facilities and infrastructure, especially relating to inter-school policy networks. Moghadam et al (2019), revealed 
how the complex and multi-dimensional nature of power relations between education and power affected the professional identity of teachers. According to Kobakhidze (2013), certification policy in some ways improved teacher performance, social status and prestige in society. Klimenko et al (2018) revealed that school teacher job had high prestige within society, was a social work and gave financial security. Ideological support from the government was highly needed. Teacher profession deteriorated due to excessive administrative burdens and high social demands.

Relating to the education policy to improve the quality and performance of teachers Rawolle (2013) mentioned that a social contract between policy makers at the school level and teachers was required. The social contract is supported by three fundamental conditions: agreement to be part of the contract, renegotiation by setting the duration of the contract and mutual accountability to the parties involved in the contract. According to Jaiani et al (2011), a concept of accountability should be developed to formulate a policy process related to improvement in teacher performance. Meijer et al (2014) revealed that study on teacher's learning had identified the development of professional identity as an inevitable focus in teacher education. Many teacher's training programs have paid attention to the development of teacher's professional identity, but studies on pedagogy is very limited whereas pedagogy is a learning goal. Pedagogy focuses on developing the professional identity of teachers. Pedagogy reflects the development of teacher's professional identity.

Teacher performance can be improved if the school is able to create a conducive work environment and atmosphere, develop a clear division of work, prepare and provide manuals or work guidelines, provide guidance and directions for teachers having problems in carrying out their duties, open opportunities for teachers to enrich or deepen their work experience as well as grow and develop motivation and work ethic. So, teacher performance in the teaching and learning process is the ability of a teacher to carry out his duties as an instructor who has expertise to educate students.

Therefore, to actualize the duties of teachers as professionals, the government through the Ministry of National Education as mandated by Law No. 20 of 2003 concerning National Education System, Law No. 14 of 2005 concerning Teachers and Lecturers and Government Regulation No. 19 of 2005 concerning National Education Standards will facilitate professional development of teachers in a sustainable manner. The Sustainable Professional Development Program (Program Pengembangan Keprofesian Berkelanjutan/PKB) is directed towards reducing the gap between knowledge, skills, social competency and personality of teachers today and the future demand of their profession.

PKB activities are developed based on the teacher performance profile obtained from the results of teacher performance assessment and supported by the results of self-evaluation. Teachers whose performance assessment results are still below the standard of compentency or in other words having poor performance are required to attend the PKB program, which is oriented towards achieving this standard. On the other hand, for those who have achieved the standard of competency, their PKB activities are directed towards improving their professionalism in carrying out their duties and obligations to meet future demands. This is in accordance with the school's needs to provide quality learning services to students.

\section{CONCLUSION}

Teacher certification is a competency test process designed to reveal mastery of one's competence as a basis for awarding educator certificates. Professional teachers are teachers who meet the qualifications, competency and certification requirements. Teacher's competency is measured against 4 components, namely: a) pedagogic competency, b) personality competency, c) social competency, d) and professional competency. If these four components of competency are met, they will make good teacher performance.

The results of the study on the impacts of the certification policy on teacher performance show that the certification policy has not been able to improve the professionalism of teachers as agents of learning in schools. In general, regarding the performance, certified teachers do not show significant differences with those who have not been certified. Differences in performance are seen in social and personality competencies. While in terms of pedagogic and professional aspects, there is no difference. Certified teachers have not been able to prove that their performance is better than those who have not been certified.

To improve the performance of teachers in schools, especially teachers who have been certified, there are several measures to be taken as follows: 1) The performance of certified teachers needs to be evaluated, which is primarily related to pedagogic and professional competencies; 2 ) The performance of certified teachers can be improved through workshops to improve professionalism, especially in the learning process, writing scientific papers, enriching material and developing general knowledge; 3 ) Certified teachers are expected to be able to improve their performance based on their own potential 
through discussions with peers and school principals; 4) To further improve teacher performance in pedagogic and professional competencies, school principals are expected to be able to give guidance and motivation to teachers, hold seminars, trainings for personal and career development.

\section{ACKNOWLEDGEMENT}

We would like to thank the Research and Community Service Institute (LPPM) of the Universitas Riau for facilitating this research. The highest award is given to the Principal, whose school has been used as a research sample especially in Kampar Regency, Rokan Hulu Regency, Pelalawan Regency, and Pekanbaru City.

\section{REFERENCES}

Amar, A. (2004), "Motivating knowledge workers to innovate: a model integrating motivation dynamics and antecedents", European Journal of Innovation Management, Vol. 7 No. 2, pp. 89101. https://doi.org/10.1108/14601060410534366.

Akkermans, J., de Lange, A., van der Heijden, B., Kooij, D., Jansen, P. and Dikkers, J. (2016), "What about time? Examining chronological and subjective age and their relation to work motivation", Career Development International, Vol. 21 No. 4, pp. 419-439. https://doi.org/10.1108/CDI-04-2016-0063

Ankli, R. and Palliam, R. (2012), "Enabling a motivated workforce: exploring the sources of motivation", Development and Learning in Organizations, Vol. 26 No. 2, pp. 710. https://doi.org/10.1108/14777281211201169.

Brown, A. (2005), "Implementing performance management in England's primary schools", International Journal of Productivity and Performance Management, Vol. 54 No. 5/6, pp. 468481. https://doi.org/10.1108/17410400510604593.

Govaerts, M, J. B., Wiel, M. W.J., and Vleuten, C.W.J. (2013), "Quality of feedback following performance assessments: does assessor expertise matter?", European Journal of Training and Development, Vol. 37 No. 1, pp. 105-125. https://doi.org/10.1108/03090591311293310

Irs, R. and Türk, K. (2012), "Implementation of the performance-related pay in the general educational schools of Estonia: Perspectives and possibilities", Employee Relations, Vol. 34 No. 4, pp. 360393. https://doi.org/10.1108/01425451211236823.

Irs, R. (2012), "Pay-for-performance in Estonian general educational schools: the situation for further development", Baltic Journal of Management, Vol. $7 \quad$ No. 3 , pp. 302332. https://doi.org/10.1108/17465261211245472.

Junior, S. CF., Fleury, A. (2018), "Performance assessment process model for international manufacturing networks", International Journal of Operations \& Production Management, Vol. 38 No. 10, pp. 19151936. https://doi.org/10.1108/IJOPM-03-2017-0183

Jaiani, V. and Whitford, A. (2011), "Policy windows, public opinion, and policy ideas: the evolution of No Child Left Behind", Quality Assurance in Education, Vol. 19 No. 1, pp. 827. https://doi.org/10.1108/09684881111107735

Kobakhidze, N. M. (2013), "Teacher Certification Examinations in Georgia: Outcomes and Policy Implications", Akiba, M. (Ed.) Teacher Reforms Around the World: Implementations and Outcomes (International Perspectives on Education and Society, Vol. 19), Emerald Group Publishing Limited, Bingley, pp. 25-51. https://doi.org/10.1108/S1479-3679(2013)0000019007.

Kongcharoen, J., Onmek, N., Jandang, P. and Wangyisen, S. (2019), "Stress and work motivation of primary and secondary school teachers", Journal of Applied Research in Higher Education, Vol. ahead-of-print No. ahead-of-print. https://doi.org/10.1108/JARHE-04-2019-0088

Klimenko, L. and Posukhova, O. (2018), "Professional identity of school teachers in the context of sociohistorical dynamics of Russian society", International Journal of Educational Management, Vol. 32 No. 5, pp. 813-824. https://doi.org/10.1108/IJEM-09-2017-0255

Liu, S., Zhao, D. and Xie, W. (2016), "Chinese teachers' attitudes toward performance pay: the cases of three schools", International Journal of Educational Management, Vol. 30 No. 6, pp. 791808. https://doi.org/10.1108/IJEM-06-2015-0074.

Meijer, P., Oolbekkink, H., Pillen, M. and Aardema, A. (2014), "Pedagogies of Developing Teacher Identity", International Teacher Education: Promising Pedagogies (Part A) (Advances in Research on Teaching), Volume 22, pp. 293-309. https://doi.org/10.1108/S1479-368720140000022018

Moghadam, H. H., Adel, S., Ghaniabadi, S. and Amirian, S. (2019), "A Bourdieusian analysis of the educational field and professional identity of EFL teachers: A hermeneutic phenomenological 
analysis", Qualitative Research Journal, Vol. 19 No. 2, pp. 156-170. https://doi.org/10.1108/QRJ-122018-0002.

Nasra, M. A and Arar, K. (2019), "Leadership style and teacher performance: mediating role of occupational perception", International Journal of Educational Management, Vol. ahead-of-print No. ahead-ofprint. https://doi.org/10.1108/IJEM-04-2019-0146

Naeem, R. and Syed, J. (2019), "A Virtue Ethics Perspective on Motivation", Harris, V. (Ed.) Ethics in a Crowded World: Globalisation, Human Movement and Professional Ethics (Research in Ethical Issues in Organizations), Vulume 22. pp. 105-118. https://doi.org/10.1108/S1529209620190000022008.

Ocham, L. and Okoth, U. (2015), "Head-teachers ' motivational practices in public secondary schools in Kenya", The TQM Journal, Vol. 27 No. 6, pp. 814-822. https://doi.org/10.1108/TQM-08-2015-0110

Orr, M., Hollingworth, L. and Beaudin, B. (2019), "Performance assessment for school leaders: comparing field trial and implementation results", Journal of Educational Administration, Vol. 58 No. 1, pp. 3859. https://doi.org/10.1108/JEA-05-2018-0087

Pablos, P. O., and Lytras, M. D (2008), "Competencies and human resource management: implications for organizational competitive advantage", Journal of Knowledge Management, Vol. 12 No. 6, pp. 4855. https://doi.org/10.1108/13673270810913612

Rawolle, S. (2013), "Emotions in Education Policy: A Social Contract Analysis of Asymmetrical Dyads and Emotion", Newberry, M., Gallant, A. and Riley, P. (Ed.) Emotion and School: Understanding how the Hidden Curriculum Influences Relationships, Leadership, Teaching, and Learning (Advances in Research on Teaching, Vol. 18), pp. 49-60.https://doi.org/10.1108/S14793687(2013)0000018007

Ree. J., Muralidharan. K., Pradhan. M., Rogers. H., (2015). double for Nothing? Experimental Evidence on the Impact of an Unconditional Teacher Salary Increase on Student Performance in Indonesia, Nber Working Paper Series. Working Paper 21806. Issued in December 2015. http://www.nber.org/papers/w21806

Rogge, N. (2011), "Granting teachers the "benefit of the doubt" in performance evaluations", International Journal of Educational Management, Vol. 25 No. 6, pp. 590614. https://doi.org/10.1108/09513541111159077

Roche, M. and Haar, J. (2019), "Motivations, work-family enrichment and job satisfaction: an indirect effects model", Personnel Review, Vol. ahead-of-print No. ahead-ofprint. https://doi.org/10.1108/PR-06-2019-0289.

Romule, K., Bak, O., Colicchia, C. and Shaw, S. (2019), "Supplier performance assessment: Evidence from a UK-based manufacturing company and its suppliers", Benchmarking: An International Journal, Vol. ahead-of-print No. ahead-of-print. https://doi.org/10.1108/BIJ-10-2018-0305

Shauki, E., Alagiah, R., Fiedler, B. and Sawon, K. (2009), "Do learner's gender and ethnicity really matter for academic performance evaluation", Journal of International Education in Business, Vol. 2 No. 2, pp. 28-51. https://doi.org/10.1108/18363261080001595

Tan, C. and Tee Ng, P. (2012), "A critical reflection of teacher professionalism in Cambodia", Asian Education and Development Studies, Vol. 1 No. 2, pp. 124138. https://doi.org/10.1108/20463161211240106

Tuytens, M. and Devos, G. (2012), "Importance of system and leadership in performance $\begin{array}{llllll}\text { appraisal", Personnel Review, } & \text { Vol. } & 41 & \text { No. } & \text { 6, }\end{array}$ 776. https://doi.org/10.1108/00483481211263692

Wang, M. and Ho, D. (2019), "A quest for teacher leadership in the twenty-first century - emerging themes for future research", International Journal of Educational Management, Vol. ahead-of-print No. ahead-of-print. https://doi.org/10.1108/IJEM-01-2019-0038 